\title{
Student's Descriptive Text Writing in SFL Perspectives
}

\author{
Eko Noprianto \\ Indonesia University of Education (UPI) \\ e-mail:noprianto.eko@student.upi.edu
}

\begin{abstract}
:
Descriptive text is one of genres which is demanded to master by high school students in Indonesia. This requires teachers to be able to deliver it well in the classroom. However, research discovered that many teachers still have limited knowledge of how to effectively teach genres in the classroom. This qualitative case study was intended to diagnose a student's descriptive text writing through SFL perspectives to find out what problems encountered in her text writing. It is expected that after finding the problems, the teacher could design a pedagogical plan to deal with them. The results showed that the student's major problems in writing descriptive text lied on three aspects: the inability in adjusting the social function of the text, difficulty in writing the descriptive text with a chronological schematic structures, and the difficulty in filling the text with appropriate language features such as the use of unspecific participant. Therefore, taking everything into consideration, the researcher proposed Discovery Learning model to be used in teaching descriptive text in the classroom due to its strengths.
\end{abstract}

Keywords: Descriptive text, Experiential Metafunction, Interpersonal Metafunction, SFL, Textual Metafunction 


\section{Introduction}

As descriptive text is included in English curriculum in Indonesia (Kemendikbud, 2013), knowing how the text should ideally be composed is essential for the teacher as the one who is responsible in delivering it in the classroom and for the students who are demanded to master it. Since descriptive text, like other text types, is not only constructed with some rigid rules in the form of sentences, but also composed by considering its purpose and the meaning of each structures, teacher needs to have enough knowledge of how those clauses make meaning. In other words, teacher should have a good the knowledge of Systemic Functional Linguistics (SFL). As conceptualized by Gerot \& Wignel (1994) that SFL tends to see language as a resource for making meaning and try to describe language in actual use focusing on texts and their contexts. Besides the need to have knowledge of SFL as the basis in teaching descriptive text, teachers should also be equipped with the capability of delivering it in the process of teaching and learning. In other words, teacher should be familiar with various pedagogical knowledge related to teaching genres in order to effectively help student understand it.

Unfortunately, in relation to teacher's pedagogical competence, research discovered that many teachers still have limited knowledge of teaching genres in the classroom as stated by Derewianka (2003) that there are three basics problems concerning on teaching genres in the classroom. Firstly, rather than focusing on the purpose and the use of the genres being taught and their relation with their functions, teachers seem to focus only on the name and the stages of genres which leads the students to the confusion. Secondly, it also seems that the teaching process tends to focus only on a small handful of genres to be taught without paying more attention to the subtypes of genres which are also actually important like teaching only a personal recount although in fact, there are other subtypes of recount like historical recount and factual recount. And thirdly, in relation to the text stages or the text schematic structures, teachers seem to introduce the stages rigidly without letting the students identify and reflect what function of each stage basically is. Teacher's lack of pedagogical knowledge, thus, might inevitably affect students' understanding in composing the target text.

After introducing and delivering the text to the students, another thing the teachers should take into account is to make sure whether the students have already mastered the text or not since it can be used as the indicator of whether the teachers are successful in teaching. Therefore, it is critical to diagnose to what extent the students already understand how to write it. One effective way to diagnose students' descriptive text writing is by seeing it in SFL (Systemic-Functional Linguistic) perspectives since it could give a deep and detailed information whether their writings meet the criteria and characteristics of descriptive text. Besides, analyzing student's writing through SFL perspectives could help teacher understand how the student creates contextual meaning in their composition through its structure and organization.

Considered to be effective in teaching writing, studies on the use of SFL in both EFL and ESL context for either teaching or analyzing students' writing have been 
conducted by many scholars focusing on various types of the texts such as Arancon (2013) focusing on students 'writing skills in ESP; Briones (2016) on a Review and News item text from textual perspectives; Correa and Dominguez (2014) for Narrative text; Emilia and Hamied (2015) focusing on Exposition text; Jing (2015) on applying Theme and Thematic progression in English writing teaching; Lirola and Irwin (2016) focusing on students' challenge in writing a report; Nurohmah (2013) on Recount text; and Rahmawati (2016) who focusses on thematic progression of Descriptive and Recount text. Meanwhile, regarding Descriptive text, some studies have been also conducted as by Siahaan (2013); Sipayung, Sinaga, Sianipar, \& Napitupulu (2016); and Anggun (2016) with different methodological approach and context.

Different from the last three mentioned studies, this paper is mainly intended to figure out how student's descriptive text writing is in SFL perspectives. Using a case study approach, this study was expected to give in-depth analysis and information regarding students' writing problems. After diagnosing their problems in writing descriptive text, it is expected that teachers could design a pedagogical plan which is used to effectively help student overcome the recurring problem found in writing the text.

\section{Literature Review}

\subsection{Descriptive text}

Descriptive text is a type of text which is used by the writer or speaker to describe particular thing, person, animal, place and or event to the readers or hearers (Gerot \& Wignel, 1994; Knapp \& Watkins, 2005). The process of describing is done through ordering their characteristics clearly, starting from naming them, classifying them, and dealing with their attributes, behaviors, functions, and so on so that the readers or hearers can possibly notice what the writer is writing about as if they could directly see it through their own eyes.

Like other genres, descriptive text also has its structure or stages. The elements or schematic structures of descriptive text are called identification or general statement and description. Identification is aimed at introducing and identifying specific participant such as a person, a thing, a place, an animal, and or an event. Description, on the other side, is structured to describe that participant from its characteristics, appearances, personality, and habits or qualities (Butt, Fahey, Feez, Spinks, \& Yallop, 2000; Derewianka, 1990; Gerot \& Wignel, 1994 ; Knapp \& Watkins, 2005).

Regarding its linguistics features, Derewianka (1990); Emilia and Christie (2013); Gerot and Wignell (1994); Knapp and Watkins (2005) state that descriptive text employs some linguistics features as summarized below:

a. Focus on specific participants as the main character;

b. Use present tense as dominant tenses; 
c. Use linking verbs or relational process frequently (is, are, has, have, belongs to) in order to classify and describe appearance or qualities and parts or functions of the participant);

d. Use action verbs or material process and behavioral process in giving additional description regarding action and behavior done by the participants in text;

e. Use mental verb or mental process when describing feelings;

f. Use adjectives and adverbs to add information to nouns (participant) and add information to verbs (actions) to provide more detailed description about the topic;

g. Use adverbial phrases to add more information about manner, place, or time and sometimes realized in embedded clause which functions as circumstances.

\subsection{Systemic Functional Linguistics}

As regards Systemic Functional Linguistic, it basically deals with how language creates meaning among the speakers. The meaning is realized by language metafunction which means that it sees language as a function which works in clauses in text seen in three types of meaning namely ideational or experiential, Interpersonal and textual (Butt et al., 2000; Gerot \& Wignel, 1994; Thompson, 2014).

\subsubsection{Descriptive text in Interpersonal metafunction}

Interpersonal meaning, according to Eggins (2004), is defined as a meaning strand emerging in a text which is the realization of speaker's expression of his relationship with the readers or speakers and the expression of his attitude toward the subject matter. In other words, interpersonal meaning deals with the speaker's social relationship which is embedded in a text. Interpersonal metafunction is realized by the Mood patterns of grammar, the component of clause as the result of combination between Subject and Finite and also Modality referred to how valid the information the speakers are saying in relation to how likely the clause is to be true and how frequently that it is true (Thompson, 2014).

Since the social purpose of descriptive text is to describe particular thing, animal, person, and phenomenon, descriptive text is ideally written in the declarative form and uses specific things as subjects such as my favorite teacher, my cat, my house, etc. To describe a technical or factual point of view of the subject, the finiteness of descriptive text is usually in the form of simple present tense with the finite is clearly stated with the use of $i$ and are in the clause e.g. my house is clean and neat or the finite is fused with the predicator e.g. my dog likes playing with the ball, my favorite teacher comes at 7 am every day, etc. However, when it tries to describe subject in the literary description such as in novel and short story, we can possibly see finiteness which is written in the form of past tense with was, were as the finite as in Julia, about a hundred and fifty centimeters tall, was a beautiful girl with an unusual habit or with the use of fusion between Finite and Predicators as in an old 
big woman ate her lunch in a hurry when she heard a scream near the building where she was sitting.

Besides Mood, it is also considered important to discuss the Residue, the combination of predicator (verbal group) and complement (nominal group) and (optionally) adjuncts (adverbial group, and or prepositional phrase) (Thompson, 2014). In the descriptive text, predicators are written apart from Finite and is usually in the form of verb 1 in the present tense such as eats, sings, lays, swims, etc. Beside predicator, Residue is formed from the emergence of adjuncts. In descriptive text, the most common adjunct which emerges is Mood adjunct in the form of Usuality such as always, frequently, usually, sometimes, etc. which talks about the subject's behavior as in this sentence: my dog always wags his tail whenever I give him food.

Another feature to be considered in descriptive text is the use of Attitude which is defined as the evaluation given by the writer or speaker on subject in the clauses (Thompson, 2014). Normally, the Attitude given is in the form of adjectives (beautiful, smart, clean, etc.) or noun group (a beautiful girl, a clean house, etc.) to express the speaker or the writer's judgment or appreciation of the subject as seen in these clauses: my mother is always angry after coming from work, my house is big, She is a lovely girl, and so on (Knapp \& Watkins, 2005).

\subsubsection{Descriptive text in experiential metafunction}

Meanwhile, experiential metafunction sees language as a set of resources as units and the ways in which those units act on or relate to each other (Thompson, 2014). In a simpler explanation, experiential metafunction deals with Transitivity, the process of actions/states involving the role of participant. From experiential perspectives, a clause is not seen from its constituent function but from the process which acts and relates each other. In this case, a clause is basically formed by the process or action/state which involves participant as both 'doers' and 'done to' in certain circumstances. Process in a clause is represented by verbal group, which has four main categories namely material processes, mental processes, relational process, and verbal processes and two additional categories which are behavioral processes and existential processes. While participant is in the form of noun group and circumstance which gives background information which is realized by adverbs and or prepositional phrase.

From the Transitivity perspectives, when descriptive text is intended to classify and describe appearances or qualities and parts or functions of the participant, Relational process, both relational attributive and relational identifying, dominates the clause with the emergence of is, are, have, and has as seen in these examples: my favorite toy is a teddy bear because it is friendly and cuddly, ant has three body parts, etc. However, when the text describes behavior or uses of the participant, Material process which is in the form of action verbs is employed as in these examples: the queen ant lays_the eggs, the birds migrate twice a year, etc. Sometimes, when the text needs to describe feelings, then Mental process usually in the form of emotive mental process, such as feel and desiderative mental process, such as want, like, 
love, etc. is used e.g. my father feels happy whenever I get high score in mathematics, she loves dancing, etc.

In addition to the process which underlies the clause in descriptive text, it is interesting to also talk about the participants. Ideally, since descriptive text discuss specific thing, person, animal, and or phenomenon, the participants involved in the formation of the clause is in the form of specific noun such as My lovely pet, My mother, My school, etc. What is interesting to see is that the terms for participants are different in accordance with the process underlying. With respect to relational process of attributive, the participant is known as carrier while in the relational process of identifying, the participants are called token and value. While the participants are known as actor and goal in material process, the participants are called senser and phenomenon in mental process.

Another point which should be taken into account is the emergence of Circumstance in the descriptive text. Often, when the speaker or writer needs to add extra information to the process to provide more detailed description, the Circumstance in the form of Manner such as slowly, beautifully, clearly, etc. and in the form of Extent such as always, usually, often, etc. as seen in this example: My grandma always_eats her lunch slowly. But if the speaker wants to add more information about the manner, place or time, he/she will use the Circumstance in the form of Role, Purpose, and Location in the clauses. E.g. turtle has a shield on his body as protector from other predators, the old man often comes late to the meeting, etc. (Knapp \& Watkins, 2005).

\subsubsection{Descriptive text in Textual metafunction}

The last perspective worth noting is Textual metafunction which is related to what roles the language plays in the context to make coherent discourse. Textual meaning of the clause is expressed by Theme and Rheme (Butt et al., 2000; Gerot \& Wignel, 1994; Thompson, 2014). Theme is what the clause is going to be about. It basically looks backwards based on what has discussed before in looking for the message. While Rheme is made through picking up information which is already available and adding by presenting information which was not mentioned before. In other words, Rheme can point both backwards and forwards (Gerot \& Wignel, 1994). Theme can be divided into a number of categories: Topical or Experiential Theme, textual Theme, and Interpersonal Theme. In descriptive text, the Theme is ideally in the form of Experiential theme or Topical theme in which the unmarked Theme is formed by specific participant or subject in declarative mood e.g. (underlined) my dog lies on my bed, he always borrows some money from his friend, etc. (Knapp \& Watkins, 2005).

Meanwhile, regarding the information exchange between back-to-back Theme and Rheme twain in a text which is known as Thematic progression (Eggins, 2004), There are three types of thematic progression: constant theme pattern, Zig-zag or Linear theme patter and Thematic drift. In descriptive text, the most common employed Theme progressions are constant theme pattern and linear progression. 


\subsection{Related Research}

Before this current research was conducted, some research has been conducted to explore descriptive text writing in SFL perspectives in Indonesian context. Siahaan (2013) in his study to investigate tenth graders' ability and difficulty in writing descriptive text found that the middle and high achievers were able to produce descriptive texts with appropriate schematic structures and language features compared to the low achievers who struggled in identifying the schematic structure of descriptive text. It was also found that low achievers still made a lot of mistakes in their writing.

Meanwhile, Sipayung, et al (2016) explored the experiential, interpersonal, textual meaning and schematic structure of seventeen university students' descriptive writing and found that majority of the students' descriptive text writing was written in the form of Relational process and was also written in the form of declarative mood. However, more than half of the students wrote improper stages of descriptive texts.

Unlike two former studies which diagnosed students' descriptive text writing, Anggun (2016) tried to find out whether the descriptive texts in English textbook meet its criteria in terms of purposes, schematic structures and linguistic features. Analyzing four descriptive texts in the textbooks, she found that one of four texts was not written to meet the purpose of descriptive text as well as its schematic structures. In relation to linguistic features, only two texts which meet the criteria of having appropriate linguistic features.

\section{Research Methodology}

Since the present study is intended to figure out how student's descriptive text writing is in SFL perspectives, a qualitative research methodology is employed. The use of qualitative design is believed to be able to explore and understand a central phenomenon which shows up in this study and is able to generate meaning and interpretation from the data which was collected i.e. student's descriptive text writing (Creswell, 2012). In relation to this, the researcher used a qualitative case study approach. The qualitative case study was preferred since the focus on the study was to explain a present circumstance such as how a social phenomenon works (Yin in Hamied, 2017, p.264). Hamied (2017) added that case study is useful when the researcher needs to address an explanatory question just like the question in this study. In addition, qualitative case study is seen appropriate to explore deeply a program, event, activity, process or one or more individuals (Creswell, 2014).

With a purposive sampling, the researcher deliberately chose a descriptive text written by a female student at the second grade of a private Islamic high school in Semarang, Central Java to be analyzed. This student's descriptive text writing was chosen based on the consideration that her text represented other students' writings in the classroom in the form of the common and recurring problems shown in the text. After choosing one text out of twelve texts given by the teacher, the researcher analyzed and diagnosed the sample to see its appropriateness with the theories underlying descriptive text starting from the social function, schematic structures, 
and language features from SFL perspectives namely interpersonal metafunction, experiential metafunction, and textual metafunction.

\section{FINDINGS}

The present study was intended to discover how student' descriptive text writing in SFL perspectives was. Realizing the research objective, the researcher analyzed student's writing in the form of its' common grammatical mistakes, its schematic structures and communicative purpose, and its three metafunctions.

\subsection{Grammatical mistakes}

In analyzing the student's descriptive text, it is considered important to start with the student's basic mistakes in writing although those mistakes could not determine whether the text meets the criteria of a descriptive text or not. However, the use of correct grammar and mechanics such as punctuation, spelling and capitalization in composing a text would be helpful to make it easily understood.

Overall, her writing showed that she had a pretty good knowledge of grammar such as knowledge of subject-verb agreement, compound sentences, and knowledge of adjectives clauses as seen from the following sample: A library is the place where someone can spend their time and (comply his) interest, etc. However, there were two common types of mistakes found in the text such as spelling (wichwhich, cildren - children, institions - institutions), and word order (Every individual big and small - every big and small individual).

Those aforementioned mistakes found in the text were probably caused by some factors. Firstly, there might be an L1 interference to the target language in term of different language structure and modes of thinking so that when she was composing a phrase or a clause, she tended to do literal translation which made her composition not well structured. That is followed by, secondly, her lack of vocabulary knowledge which lead her to directly write what she read from dictionary into her writing, and thirdly, since it was an on-the spot writing, there is a possibility that she ran out of the time when writing the text which made her difficult to do reviewing and revising.

\subsection{Schematic Structure and Social Purpose}

As stated earlier that an ideal descriptive text should be written with a purpose to describe a particular thing, person, place, animal and or event (Derewianka, 1990; Gerot \& Wignell, 1994; Knapp \& Watkins, 2005). Therefore, it is important to see first whether the text has already met its social purpose or not. However, after being analyzed, it is found that this text talked library in general instead of talking about specific library as seen from several sentences at the beginning of the text: library is a heaven for a student, teacher, (and of) course for those who like reading. The clause is continued with: this is the place where someone can get unlimited stocks of.... Moreover, the library description cannot be found in the second paragraph in which the writer still talked about what library is used for. Even in the fourth and fifth paragraph, the writer discussed the importance of reading and how to develop reading habit as seen in this sentences: every individual big and small must develop 
the habit of reading, and reading is the best hobby we can develop, etc. Therefore, it is quite difficult to say that the text has already met the criteria of descriptive text in the form of social purpose. To be a descriptive text, the text should, for instance, describe her school library, or a national library which makes the participant specific.

With respect to its schematic structures, it is also found that the text does not fully meet the schematic structures of a descriptive text which should have a general statement and description in it. At the first paragraph, for instance, she wrote the general statement of the library by explaining what library is, and what can be found in a library. In the second and third paragraph, she still mentioned the definition of library, the benefit of a library as a place for spending time, and where to find library. Another point which is interesting to discuss is the content of the last two paragraphs, she added other information related to how important it is to have a reading habit and how useful book is for people. She also encouraged readers to improve their reading habit in the last paragraph.

Therefore, seeing these content of structures, it was arguably concluded that the student tried to describe the library in general in the first two paragraphs which, in some parts, leads it to be a reports text which has a function to describe the way things are with reference to a range of natural, manmade and social phenomena in our environment (Gerot \& Wignel, 1994). Besides, it can probably be assumed that, from the last two paragraphs, rather than writing a descriptive text, her text is more like a structure of arguments and recommendation in a hortatory exposition since it contains reasons for concern and statements of what ought to or ought not to happen (Gerot \& Wignel, 1994).

\subsection{Language features from SFL perspectives}

\subsubsection{Interpersonal metafunction}

Since Interpersonal metafunction deals with social relationship which is created and maintained in a text and is realized by the Mood patterns of grammar, analyzing this text would be started from its system of Mood.

From the system of Mood, it showed that all clauses in her text were written in declarative Mood in the form of positive Polarity. The way she wrote her text using declarative mood is considered relevant with the purpose of descriptive text which is to give information to the readers. In addition, majority of the clauses was also written in present tense with is as the Finite and only one clause which was written in the form of the fusion of Finite and lexical verb. The use of present tense here possibly means that she had enough knowledge on its use when describing a technical or factual point of view of the subject.

However, it was found that there were five clauses which were composed using Modal Finite, four expressing the ability (can) and one expressing the obligation (must). The use of modal finiteness in a descriptive text showed that the she probably intended to include her personal opinion to the readers especially when they are combined with a general participant as seen from these clauses: We can 
also find libraries in all schools and colleges, Every individual big and small must develop the habit of reading, the habit of reading can be developed, etc. which unfortunately might be considered irrelevant to a descriptive text's characteristics.

In relation to the participants written in her text, there seems to be a discrepancy with the characteristics of a descriptive text in which the participant should be in a specific one (Derewianka, 1990; Gerot \& Wignell, 1994; Knapp and Watkins, 2005; Emilia and Christie, 2013). This was proved by the use of library as the main character followed by other subjects such as reading, the habit of reading, we, they and every individual. In other words, this text did not seem to focus on one particular participant as the subject and when they are combined with the aforementioned clauses, it is quite difficult to lead the text into a descriptive text.

\subsubsection{Experiential metafunction}

From the Transitivity system in which the text is realized through the process of actions which involves the role of participants (Butt et al, 2000; Thompson, 2014; Emilia \& Hamied, 2015), it can be summarized that majority of her clauses was structured by almost $60 \%$ of Relational process with 9 clauses in the form of Identifying and one clause in the form of Attributive and $40 \%$ of Material process. The use of Relational process indicated that she had realized that she should describe and explain functions of the participant to make the readers understand the topic she choose when writing a descriptive text although the token and carrier which she used are not in the form of specific participant as seen in these clauses: Library (token) is a heaven for a student, teacher, (and) course for all those who like reading, A library (token) is the place where someone can spend their time, etc. Meanwhile, the use of Material process in her text showed that she probably intended to give additional description regarding the action done by the participant (actor) as seen in these clauses: They can learn so much by reading books, no outsider is even allowed in any of the libraries of institions (institutions), We can also find libraries in all schools and colleges, etc.

However, since descriptive text talks about participant's characteristics, appearances, personality, and habits or qualities, it is probably important to have Behavioral process to describe the habit and appearances of the participant and also Mental process to explain the sense of the participant. Unfortunately, those mentioned processes cannot be found in this text which might make it become less descriptive.

\subsubsection{Textual metafunction}

Another perspective worth noting is from Textual metafunction which is related to what roles the language plays in the context to make coherent discourse. Textual meaning of the clause is expressed by Theme and Rheme (Gerot \& Wignell, 1994; Butt et al, 2000; Thompson, 2014).

From the sample of the text, it was found that all Themes in the text are in the form of unmarked Topical Theme, majority of which is in the form of Noun group. It is noted that there were eleven Themes in the form of noun group with We, This and 
reading as the most Themes frequently used in the text. Moreover, There are also found five Textual Themes in the form of conjunctive: and (used twice), even though, only if, and beside. The use of these five textual Themes here can be concluded that she wanted to relate the clause to the preceding clauses by providing a logical link between the messages stated in each clause in order to get coherent clauses.

However, her effort to link the messages using several conjunctions seems to fail since the message from previous clause was not logical with the message of the proceeding clause as seen in the following figure:

A library is the ideal place and reading is an ideal pastime.

\begin{tabular}{|l|l|l|l|l|}
\hline A library & $\begin{array}{l}\text { is the ideal } \\
\text { place }\end{array}$ & And & reading & $\begin{array}{l}\text { is an ideal } \\
\text { pastime }\end{array}$ \\
\hline Topical & & Textual & Topical & \\
\hline Theme 1 & Rheme 1 & Theme 2 & Rheme 2 \\
\hline
\end{tabular}

Figure 1. The relationship between two clauses with conjunction

From the figure above, it can be seen that there was no relation between two clauses. Even, theme 2 is not developed from theme 1 or Rheme 1 in which it should be. In other words, the placement of conjunction there seems ineffective since the two clauses in which the conjunction is put is contradictory in meaning.

In relation to the way the writer constructed each clauses into a text, it showed that she had made an effort to make her paragraph coherent by developing proceeding Themes from previous Theme as evidenced in the first paragraph of the text below:

\begin{tabular}{|c|c|}
\hline Library & $\begin{array}{l}\text { is a heaven for a student, teacher, (and) course for all those who like } \\
\text { reading. }\end{array}$ \\
\hline Theme 1 & Rheme 2 \\
\hline This & $\begin{array}{l}\text { is the place where someone can get unlimited stocks of-en any andevery } \\
\text { subject.... }\end{array}$ \\
\hline Theme 2 & Rheme 2 \\
\hline
\end{tabular}

Figure 2. The Theme development

The figure above which is considered as the general statement or identification, showed that she developed the second Theme from Theme 1 by adding the word 'this' to refer to the Theme from the previous clause. The ability of developing Theme from previous Theme or Rheme is basically important to help the readers predict what come next or what the writer is going to talk about in the following clauses (Gerot \& Wignell, 1994).

However, the way she composed each clause seems inconsistent. Better development of Theme only occurred in the first and second paragraph. In the rest paragraph, third to fifth paragraph, the writer seemed to struggle in making her clauses related to each other or coherent as seen in the fifth paragraph below: 


\begin{tabular}{|c|c|c|}
\hline Reading & \multicolumn{2}{|r|}{ is the best hobby we can develop and the best companion to spend time. } \\
\hline Theme & \multicolumn{2}{|r|}{ Rheme 1} \\
\hline \multicolumn{3}{|c|}{ is the ideal place } \\
\hline \multicolumn{3}{|c|}{ Theme 2} \\
\hline and & \multicolumn{2}{|c|}{ reading is an ideal pastime. } \\
\hline Textual & topical & \multirow[t]{2}{*}{ Rheme 3} \\
\hline \multicolumn{2}{|c|}{ Theme 3} & \\
\hline
\end{tabular}

Figure 3. Theme development inconsistent

From the figure above, it can be seen that the first and the second clauses were not well linked since Theme 2 had nothing to do with the Theme of the first clause (Theme 1) and even with the Rheme 1. Rather, Theme 1 is related to topical Theme 3. However, those clause would be coherently written if Theme 3 were substituted by it rather than reading and certainly, the second clause should be omitted.

Moreover, with respect to each paragraph relationship, the writing sample indicates that the writer also had difficulty in developing the schematic structure in the form of description from the general statement or identification in the first paragraph as seen below:

Library is a heaven for a student, teacher, (and) eourse for all those who like reading. This is the place where someone can get unlimited stocks of on any and every subject(s) that may be for interest(ing) or just need for an individual (need).

Every (big and small) individual big and small must develop the habit of reading(.), (it can be) just for fun, (or) and to gain knowledge(.), (reading) may (not) be net enly (done only) for exam. This is because reading is a good habit and book is the best friend. The habit of reading can be developed only if we get into the habit of going to a library and spending a lot of time there.

Figure 4. Paragraph interrelatedness

From the figure above, it was found that the Theme of first paragraph and the Theme of the proceeding paragraphs were not interrelated in which the first paragraph talked about the Library while the following paragraph mainly talked about reading habit. This indicated that the writer was unable to create a good control of the demands of the generic form of a descriptive text to achieve the purpose of the genre. In other words, the Theme choice in the proceeding paragraphs made the text become less descriptive. Rather, the structure of the paragraph lead it to a hortatory exposition text. 


\section{DISCUSSION}

Based on the student' descriptive text analysis result, it could be summarized that the major problem of the student in writing descriptive text lies on three issues namely the inability in adjusting the social function of the text, difficulty in writing the descriptive text with a chronological schematic structures, and the difficulty in filling the text with appropriate language features.

In relation to descriptive text's schematic structures. the finding was almost similar to the result of previous research which found that students still have difficulty in identifying the schematic structures of the text especially for low achievers (Siahaan, 2013). Even, these problems were also found in university students' descriptive texts as discovered by Sipayung et al. (2016) that eleven out of seventeen students' text were not equipped with proper schematic structures. These findings also seem in line with Anggun's (2016) findings in her study when diagnosing an English textbook used for high school which found that some descriptive texts written in the textbook did not meet a criteria of an ideal descriptive text in the form of schematic structures and language features.

Knowing what causes the student's problems in writing descriptive text to occur might be difficult since many factors which could contribute to students' success in the process of learning. As stated by Richards (2002), effective and quality teaching can be achieved not only as a result of how well a teacher delivers the materials in the classroom, but also as a consequence of how well a working environment is made which can facilitate a good teaching. He added that factors which are fundamental in creating effective teaching are Institutional Factors, teacher factors, teaching factors, and learner factors. With respect to teaching factor and teacher factor, as the one who is demanded to teach descriptive text to the students, teacher is required not only to have a professional competence in relation to good knowledge of all genres to be taught, but also to have a pedagogical competence related to the ability to select and to design a teaching and learning process which could overcome students' problems in writing descriptive text. Therefore, seeing the result of student's descriptive text writing analysis, the researcher assumed that the problems could be possibly overcome by using Discovery learning.

Discovery learning is an instructional model and strategy in teaching which is grounded from the theories of John Dewey, Jean Piaget, and Lev Vygotsky focusing on an active and hands-on learning activities for students (Castronova, 2002). Sunardi \& Sujadi (2016) added that discovery learning is believed to be able to encourage students to understand the concept, meaning, and causal relationship of teaching material so that the learners are able to generalize and make conclusion at the end of teaching process. Furthermore, as stated by Bicknell-holmes \& Hoffman (2000) that Discovery learning is considered suitable in the $21^{\text {st }}$ century teaching paradigm since it covers three main attributes: firstly, this teaching model helps students explore and solve the problems through certain activities such as creating, combining and generalizing knowledge. Secondly, the activities provided in this teaching model focus on student's centeredness in which they could learn at their own pace meaning they could determine how frequently and what sequent learning 
activities they could achieve which will probably foster their motivation in learning. Thirdly, discovery learning provide activities which combine their existing knowledge as the learning basis with their new knowledge they will get. Moreover, besides being proposed by government in 2013 curriculum which means that teachers are expected to use it in teaching and learning process together with other teaching models such as Problem-based learning, Project-based learning, and scientific approach, Discovery learning is believed to lead students' success in learning such as in academic achievement, learning retentions scores as well as their perception and motivation (Balim, 2009; Alfieri, Brooks, Aldrich, \& Tenenbaum, 2011; Castronova, 2002).

In the module of 2016 Teacher Profession Training and Education (PLPG) developed by Education and Culture Ministry, Sunardi \& Sujadi (2016) explained five steps of teaching using discovery learning. It starts with problems identification in which the students are given opportunity to identify as many problems as possible related to the teaching materials to be solved. The second step is known as Collecting Information in which the students are guided to collect and explore the information which is used to relate them to the identified problems. After that, the students are invited to process the information they have explored followed by verification or proof process where the students test the information they explore whether it could solve the problems. Lastly, the learning process is finalized by guiding the students to make a conclusion or generalization.

With respect to the three major problems found in student' descriptive text writing, the researcher believes that teaching instructions which are designed by using theories of discovery learning could help student understand how to compose a good descriptive text. In relation to the students' difficulty in adjusting the social function of the text, for instance, the students could be given some activities which emphasize more on how to determine and analyze some descriptive texts' communicative purpose and generic structures in Verification stage after being given opportunities to learn guided by teacher in collecting information and processing information stages. Meanwhile, the activities such as jumbled sentences and jumbled paragraphs in Verification stage could be useful in dealing with students' difficulty in making their descriptive text coherent (textual metafunction) by having them get used to in practicing the coherence between sentences or between paragraphs. Lastly, regarding students' difficulty in using specific participant as the subject of the text, It seems to be important to emphasize their understanding of this matter in the processing information stage along with emphasizing the social function of the text since understanding social function of descriptive text cannot be separated with the participant.

\section{CONCLUSION AND RECOMMENDATION}

The focus of the study was to analyze student's descriptive text writing to find out what problems they encountered in writing the text so that the teacher could design a pedagogical plan to deal with the problems. It was found that the major problem of the student in writing descriptive text lies on three issues namely the inability in adjusting the social function of the text, difficulty in writing the descriptive text with 
a chronological schematic structures, and the difficulty in filling the text with appropriate language features such as the use of inappropriate specific participant and inappropriate tense.

Therefore, the teacher as the one who has the responsibility to help the students as well as the authority to conduct a good teaching activities should emphasize on those mentioned problems when designing and conducting the process of teaching descriptive text. Taking everything into consideration, the researcher proposed Discovery Learning model to be used in teaching descriptive text in the classroom. Besides being one of teaching models proposed in 2013 curriculum, discovery learning is believed to be suitable for the $21^{\text {st }}$ century teaching paradigm in which the students are encouraged to be autonomous learner, it also provides activities which helps students explore and solve the problems through certain activities such as creating, combining and generalizing knowledge.

However, since the current study was limited only on one sample text to analyze, the result and the implications are difficult to generalize to other students or other group of students. Therefore, it is recommended to get more information by conducting further research with larger samples and could be triangulated with some interviews to see what the students really need and what problems they might encounter in writing descriptive text.

\section{ACKNOWLEDGEMENT}

This research is supported by Indonesia Endowment Fund for Education (LPDP) scholarship.

\section{REFERENCES}

Alfieri, L., Brooks, P. J., Aldrich, N. J., \& Tenenbaum, H. R. (2011). Does discovery-based instruction enhance learning? Journal of Educational Psychology, 103(1), 1-18. https://doi.org/10.1037/a0021017.

Anggun, S. K. (2016). An analysis of descriptive text in English textbook using transitivity system (A case study of reading passages). Journal of English and Education, 4(1), 147-158.

Arancon, P.R. (2013). The use of SFL genre theory for the analysis of students' writing skills in ESP. Volumen Monografico, 245-262.

Balim, A. G. (2009). The effects of discovery learning on students' success and inquiry learning skills. Eurasian Journal of Education Research, (35), 1-20.

Bicknell-holmes, T., \& Hoffman, P. (2000). Engage, elicit, experience, explore: Applying discovery learning to library instruction. In 2000 Tri-Conference. Nebraska: Library Conference Presentations and Speeches. Retrieved from htp://digitalcommons.unl.edu/library_talks/29.

Briones, R.R.Y. (2016). Textual analysis through Systemic Functional Linguistics. Journal of English Language Teaching and Linguistics. 1(2), 109-144. http://dx.doi.org/10.21462/jeltl.v1i2.27.

Butt, D., Fahey, R., Feez, S., Spinks, S., \& Yallop, C. (2000). Using functional 
grammar: An explore's guide ( $2^{\text {nd }}$ Ed.). Sydney: National Centre for English Language Teaching and Research Macquarie University.

Castronova, J. A. (2002). Discovery learning for the 21st Century: What is it and how does it compare to traditional learning in effectiveness in the 21 st entury? Action Research Exchange, 1(1), 1-12. Retrieved from http://www.myenglishpages.com/files/1282044031.pdf.

Correa, D., \& Domínguez, C. (2014). Using SFL as a tool for analyzing students' narratives. HOW, A Colombian Journal for Teachers of English, 21(2), 112133.

Creswell, J. W. (2012). Educational research: Planning, conducting, and evaluating quantitative and qualitative research (4th Ed.). Boston: Pearson.

Creswell, J. W. (2014). Research Design: Qualitative, quantitative, and mixed methods approaches (4th ed.). California: SAGE Publications, Inc.

Derewianka, B. (1990). Exploring how text work. Australia: Primary English Teaching Association.

Derewianka, B. (2003). Trends and issues in genre-based approaches. RELC Journal. https://doi.org/10.1177/003368820303400202.

Eggins, S. (2004). An introduction to systemic functional linguistics $2^{\text {nd }}$ Ed. New York: Continuum.

Emilia, E., \& Christie, F. (2013). Factual genres in English: Learning to write, read, and talk about factual information. Bandung: Rizqi Press.

Emilia, E., \& Hamied, F. A. (2015). Systemic functional linguistic genre pedagogy (SFL GP) in a tertiary EFL writing context in Indonesia. TEFLIN Journal, 26(2), 155-182. https://doi.org/10.15639/teflinjournal.v26i2/155-182.

Gerot, L., \& Wignel, P. (1994). Making sense of functional grammar. Queensland: Gerd Stabler, AEE Publishing.

Hamied, F. A. (2017). Research methods: A guide for first-time researchers. Bandung: UPI Press.

Jing, W. (2015). Theme and thematic progression in English writing teaching. Journal of Education and Practice. 6(21), 178-187.

Knapp, P., \& Watkins, M. (2005). Genre, text, grammar. Sydney: University of New South Wales Press Ltd.

Kemendikbud. (2013). Lampiran permendikbud nomor 69 tahun 2013 tentang kerangka dasar dan struktur kurikulum sekolah menengah atas/madrasah aliyah. Jakarta: Kemendikbud.

Lirola, M.M., Irwin, D.S. (2016). Challenges in the application of genre theory to improve L2 academic writing: Effective Reports and Assessment. ASIAN TEFL. 1(1), 39-54. http://dx.doi.org/10.21462/asiantefl.v1i1.4.

Nurohmah, I. (2013). An analysis of students' recount text by using Systemic Functional Grammar. Passage, 1(2), 89-98.

Rahmawati, A. (2016). Thematic progression in descriptive and recount texts written by nursing students. Presented in The 3rd University Research Colloquium. 102-108.

Richards, J.C. (2002). Curriculum development in language teaching. Cambridge University Press. 
Siahaan, J. (2013). An analysis of students' ability and difficulties in writing descriptive texts. Journal of English and Education, 1(1), 114-121. Retrieved from http://ejournal.upi.edu/index.php/L-E/article/view/355/244

Sipayung, K. T., Sinaga, N. T., Sianipar, M. O. C., \& Napitupulu, F. D. (2016). Metafunction realization on students' descriptive paragraphs. International Journal of Linguistics, 8(6), 20. https://doi.org/10.5296/ijl.v8i6.10264.

Sunardi, \& Sujadi, I. (2016). Sumber belajar penunjang PLPG 2016 materi pedagogik: Bab $V$ desain pembelajaran. Jakarta: Dirjen Guru dan Tenaga Kependidikan Kemendikbud.

Thompson, G. (2014). Introducing functional grammar ( $3^{\text {rd }}$ Ed.). New York: Routledge. 